\title{
Managing Conflict in New Ventures
}

\section{Daniel Forbes (University of Minnesota, Carlson School of Management)}

\author{
KEYWORDS: Management of Companies \& \\ Enterprises, Entrepreneurship, Management.
}

Conflicts arise in any human undertaking, and new ventures are no exception. One of the most puzzling things about human conflict is that it can prompt people to act in ways that undermine their own long-term interests. In a new venture setting, for example, a business with very real promise can be derailed by failures of execution or losses of human capital that stem, ultimately, from poorly managed conflicts among people involved in the venture. In this commentary, I review some recent research that can help entrepreneurs and others to understand and respond more effectively to the conflicts that arise in new ventures.

\section{What is Conflict, and Why Does It Matter?}

Conflict is "a process in which one party sees its interests opposed or negatively affected by another party" (Wall \& Callister, 1997: p. 517). Conflict can take several forms, but two forms are especially important: task conflict and relationship conflict (Barki \& Hartwick, 2004). Task conflict arises when people in a group disagree about some aspect of the task they're performing: for example, disagreements about what the task consists of or how it should be carried out. Relationship conflict happens when the disagreements are personal: for example, when they have to do with an individual's character or personality, or when people's interactions are charged with negative emotions. Task conflict and relationship conflict sometimes occur at the same time -- in fact, it is common for one to lead to the other (Jehn \& Bendersky, 2003). But task and relationship conflict are distinct forms of conflict, and it is possible to have one without the other.

Research has shown that conflict affects how well groups perform. Relationship conflict, in particular, has been shown to be overwhelmingly detrimental to a group's task performance (DeDreu \& Weingart, 2003). The effects of task conflict are more complex, but it sometimes can derail performance as well. For

example, prolonged task conflict can eat up scarce resources and create uncertainties that make it hard for groups to collaborate (DeDreu \& Weingart, 2003). However, task conflict can also help groups solve hard problems by enabling people to better identify and evaluate alternative solutions (Eisenhardt, Kahwajy \& Bourgeois, 1997).

\section{Where Does Conflict Arise in New Ventures?}

Perhaps the most common new venture conflicts are those that arise among co-founders (Ensley \& Hmieleski, 2005). These often involve differences pertaining to ownership stakes, venture control or venture strategy. Another common form of conflict arises between founders and investors: Investors are generally brought in to help a venture grow, but founders sometimes do not anticipate the loss of control that outside investment can entail. Conflicts can also arise among members of a venture's board (Forbes et al., 2010), as my colleagues and I observed in this research article (https://www.sciencedirect.com/science/article/abs/pii/S 0883902609000251). For example, differences may arise between early-stage and later-stage investors. Broader conflicts can arise among employees of a new venture. For example, divisions may form between the "early hires" of a venture and those hired later on. Such divisions may stem from disagreements that arise as a venture's structures and activities change over time in response to the demands of growth.

In all of these cases, shared equity ownership can help align the interests of the various parties, but it is important to recognize several limits of this approach. First, many people are motivated by other things besides the money and control that come with equity ownership. Second, people with aligned interests can still disagree strongly about the right way to proceed. This may occur due to differences in how people interpret a strategic situation or due to differences in the 
ethical principles they hold. It is also important to recognize that effective conflict resolution may not simply boil down to a question of who has the most power: "Winners" and "losers" of a given conflict often need to keep working together over time, and forms of conflict resolution that are too crude or abrupt can diminish the trust and morale required for effective collaboration over the long term.

\section{How Should Entrepreneurs Respond to Conflict?}

For entrepreneurs and others involved in new ventures, the key challenges are to: 1) anticipate both task and relationship conflict as common occurrences in any setting; 2) recognize - and distinguish - both forms of conflict when they occur; 3 ) look for ways to defuse relationship conflict soon after it arises; and 4) try to cultivate and leverage the constructive aspects of task conflict.

Three powerful tools for dealing with conflict are openness, mutuality and emotional self-awareness. Groups practice openness when members feel comfortable voicing their opinions and talking with one another about what is happening in and around the group. Openness is constructive because it enables groups to recognize conflict when it occurs and to distinguish more easily between task and relationship conflict (Jehn \& Bendersky, 2003). Openness also diminishes the likelihood that simple task conflicts will be suppressed and "driven underground," only to reemerge later as relationship conflicts. But openness is most effective when it is combined with mutuality, which exists when group members genuinely believe that they are working towards a common goal or a common set of interests (Amason \& Sapienza, 1997). Mutuality helps take the edge off of task conflicts by rendering them less personally threatening and, therefore, less likely to degenerate into relationship conflict. Emotional selfawareness is powerful, because emotions are a critical lever where conflict is concerned. Positive emotions tend to "lessen the negative effects of conflict while increasing the positive effects," while negative emotions have exactly the opposite effect (Jehn \& Bendersky, 2003; p. 220-223). Inducing positive emotions, of course, is a subtle task and is not always feasible in the pressure-filled, time-constrained settings that characterize many new ventures. At a minimum, however, emotional self-awareness can mitigate the risk that negative emotion will trigger dysfunctional forms of conflict, such as unchecked relationship conflict (Brown et al., 2007).

\section{Next Steps}

What practical steps can entrepreneurs take to manage conflict in their ventures? One step is to build into the firm's hiring process some consideration of the conflict management skills job candidates will bring to the organization. For example, candidates could be asked to explain how they handled a prior instance of workplace conflict. People who show evidence of openness and self-awareness are likely to manage conflict more effectively. One entrepreneur keenly aware of how hiring affected his firm's culture over time was Southwest Airlines founder Herb Kelleher, who often stated that he sought job candidates with a "superb attitude."

Another step is to build in workplace practices that foster openness and emotional self-awareness. For example, work in a new venture often involves a series of successes and failures that have emotional consequences for all involved (Shepherd, 2004). Making time for co-workers to set aside day-to-day responsibilities (e.g., through parties, games or rituals) and acknowledge the joy and sadness they feel in conjunction with these episodes can help create an environment in which it's easier for people to retain a sense of emotional self-awareness. Another useful practice is to seek coaching or mentoring from outside the venture. For example, Jerry Colonna, a venture capitalist who has lived and observed the emotional challenges of new venture management, now writes a blog, which you can link to here (http://www.themonsterinyourhead.com), designed to help entrepreneurs and those who work with them retain a sense of mindfulness in their work. A more general resource on these issues is Ashkanasy \& Daus's (2002) Academy of Management Executive article, "Emotion in the workplace" (details below).

Finally, entrepreneurs can structure roles and tasks within the venture in ways that reinforce a sense of mutuality among employees, especially employees who have to work together closely. To this end, it makes sense to pay careful attention to the goals of individual employees. People performing closely interdependent tasks will generally encounter less conflict if they are focused on a shared goal, as opposed to conflicting goals. To some extent managers can shape people's 
goals through the design of incentives (e.g., through compensation plans). But they can also foster goal alignment by encouraging employees to talk about the variety of goals they hold (which may include learning, experience and responsibility as well as financial goals) and by structuring work processes in ways that align with the goals people bring to their work.

\section{References}

Amason, A. \& Sapienza, H. 1997. The effects of top management team size and interaction norms on cognitive and affective conflict. Journal of Management, 23: 495-516.

Ashkanasy, N. \& Daus, C. 2002. Emotion in the work place: The new challenge for managers. Academy of Management Executive, 16: 76-86.

Barki, H. \& Hartwick, J. 2004. Conceptualizing the construct of interpersonal conflict. International Journal of Conflict Management, 15, 216-244.

Brown, K., Ryan, R. \& Creswell, J.D. 2007. Mindfulness: Theoretical foundations and evidence for its salutary effects. Psychological Inquiry, 18: 211-237.

DeDreu, C. \& Weingart, L. 2003. Task versus relationship conflict, team performance and team member satisfaction: A meta-analysis. Journal of Applied Psychology, 88: 741- 749.

Eisenhardt, K., Kahwajy, J. \& Bourgeois, L.J. 1997. Conflict and strategic choice: How top management teams disagree. California Management Review, 39: 42-62.

Ensley, M. \& Hmieleski, K. 2005. A comparative study of new venture top management team composition, dynamics and performance between university-based and independent start-ups. Research Policy, 34: 1091-1105.

Forbes, D., Korsgaard, M.A. \& Sapienza, H. 2010. Financing decisions as a source of conflict in venture boards. Journal of Business Venturing, 25: 579-592.

Jehn, K. \& Bendersky, C. 2003. Intragroup conflict in organizations: A contingency perspective on the conflictoutcome relationship. In R. Kramer \& B. Staw (Eds.), Research in Organizational Behavior, 25: pp. 189-244.

Oxford, UK: Elsevier.
Shepherd, D. 2004. Educating entrepreneurship students about emotion and learning from failure. Journal of Business Venturing, 3: 274-287.

Wall, J. \& Callister, R. 1995. Conflict and its management. Journal of Management, 21, 515-558. 